\title{
Calcineurin Interacts with the Serotonin Transporter C-Terminus to Modulate Its Plasma Membrane Expression and Serotonin Uptake
}

\author{
Mathieu Seimandi, ${ }^{1,2,3,4 *}$ Pascal Seyer,,${ }^{1,2,3,4 *}$ C. Sehwan Park, ${ }^{5}$ Franck Vandermoere, ${ }^{1,2,3,4}$ Benjamin Chanrion,,${ }^{1,2,3,4}$ \\ Joël Bockaert, ${ }^{1,2,3,4}$ Isabelle M. Mansuy, ${ }^{5}$ and Philippe Marin ${ }^{1,2,3,4}$ \\ ${ }^{1}$ Centre National de la Recherche Scientifique, UMR-5203, Institut de Génomique Fonctionnelle, F-34094 Montpellier, France, ${ }^{2}$ Institut National de la Santé \\ et de la Recherche Médicale, U661, F-34094 Montpellier, France, ${ }^{3}$ Université Montpellier 1, F-34094 Montpellier, France, ${ }^{4}$ Université Montpellier 2 , F-34094 \\ Montpellier, France, and ${ }^{5}$ Brain Research Institute, Medical Faculty of the University of Zürich and Department of Health Science and Technology of the \\ Swiss Federal Institute of Technology, CH-8057 Zürich, Switzerland
}

Homeostasis of serotonergic transmission critically depends on the rate of serotonin reuptake via its plasma membrane transporter (SERT). SERT activity is tightly regulated by multiple mechanisms, including physical association with intracellular proteins and posttranslational modifications, such as phosphorylation, but these mechanisms remain partially understood. Here, we show that SERT C-terminal domain recruits both the catalytic and regulatory subunits of the $\mathrm{Ca}^{2+}$-activated protein phosphatase calcineurin $(\mathrm{CaN})$ and that the physical association of SERT with CaN is promoted by CaN activity. Coexpression of constitutively active CaN with SERT increases SERT cell surface expression and 5-HT uptake in HEK-293 cells. It also prevents the reduction of 5-HT uptake induced by an acute treatment of cells with the protein kinase $\mathrm{C}$ activator $\beta$-PMA and concomitantly decreases PMA-elicited SERT phosphorylation. In addition, constitutive activation of $\mathrm{CaN}$ in vivo favors 5-HT uptake in the adult mouse brain, whereas CaN inhibition reduces cerebral 5-HT uptake. Constitutive activation of $\mathrm{CaN}$ also decreases immobility in the forced swim test, indicative of an antidepressant-like effect of CaN. These results identify $\mathrm{CaN}$ as an important regulator of SERT activity in the adult brain and provide a novel molecular substrate of clinical interest for the understanding of increased risk of mood disorders in transplanted patients treated with immunosuppressive CaN inhibitors.

\section{Introduction}

Homeostasis of serotonergic transmission critically depends on serotonin (5-HT) reuptake into presynaptic neurons via its plasma membrane transporter SERT, a member of the $\mathrm{Na}^{+} / \mathrm{Cl}^{-}$dependent transporter family (SLC6) (Torres et al., 2003; Murphy and Lesch, 2008). SERT is of major pharmacological and clinical interest as it represents the primary target of several widely prescribed antidepressants, such as selective serotonin reuptake inhibitors (SSRIs) (Jayanthi and Ramamoorthy, 2005; White et al., 2005; Millan, 2006). Moreover, alteration of SERT functional status has been associated with numerous psychiatric disorders, including anxiety and depression (Torres et al., 2003;

\footnotetext{
Received Jan. 7, 2013; revised Aug. 30, 2013; accepted Sept. 4, 2013

Author contributions: P.S., J.B., I.M.M., and P.M. designed research; M.S., P.S., C.S.P., F.V., and B.C. performed research; M.S., P.S., C.S.P., F.V., B.C., and P.M. analyzed data; P.S., J.B., I.M.M., and P.M. wrote the paper.

This work was supported by Fondation pour la Recherche Médicale (Contracts Equipe FRM 2005 and 2009), Agence Nationale de la Recherche (ANR-08-MNPS-034), Centre National de la Recherche Scientifique, Inserm, and la Région Languedoc-Roussillon to P.M., the University Zürich, the Swiss Federal Institute of Technology, and the Swiss National Research Foundation to I.M.M. Mass spectrometry experiments were performed using facilities of the Functional Proteomic Platform of Montpellier Languedoc-Roussillon.

The authors declare no competing financial interests.

*M.S. and P.S. contributed equally to this work.

Correspondence should be addressed to Dr. Philippe Marin, Institut de Génomique Fonctionnelle, 141 rue de la Cardonille, F-34094 Montpellier Cedex 5, France. E-mail: philippe.marin@igf.cnrs.fr.

DOI:10.1523/JNEUROSCI.0076-13.2013

Copyright $\odot 2013$ the authors $\quad 0270-6474 / 13 / 3316189-11 \$ 15.00 / 0$
}

Murphy and Lesch, 2008). Characterizing the cellular mechanisms that regulate SERT-mediated 5-HT clearance may thus improve our understanding of these disorders and suggest new strategies for therapeutic intervention.

Increasing evidence indicates that multiple regulatory mechanisms control SERT plasma membrane expression and catalytic activity. These include a complex combination of phosphorylation events on SERT Ser, Thr, and Tyr residues and SERT association with accessory/scaffolding proteins (Steiner et al., 2008; Zhong et al., 2012). Many SERT partners have been identified by means of two-hybrid screens and/or coimmunoprecipitation, often based on their previously described interactions with other SLC6 family transporters (Bauman et al., 2000; Haase et al., 2001; Jess et al., 2002; Carneiro and Blakely, 2006; Müller et al., 2006; Ahmed et al., 2008; Carneiro et al., 2008; Steiner et al., 2009). Proteomics strategies have also been successfully used to identify proteins interacting with SERT C terminus, in line with the importance of this domain in the localization and activity of SERT (Larsen et al., 2006). They revealed an association of SERT with the intermediate filament protein vimentin in platelets, which controls the cellular distribution of SERT (Ahmed et al., 2009). We likewise demonstrated that the extreme $\mathrm{C}$ terminus of SERT (15 C-terminal amino acids) recruits in brain two PDZ proteins, neuronal nitric oxide synthase (nNOS) and channel interacting PDZ protein, and two proteins of the coat complex II (COPII), 
Sec23A and Sec24C (Chanrion et al., 2007). Further studies showed that SERT/nNOS interaction sequesters SERT in intracellular compartments whereas SERT association with Sec24C is required for its export from the endoplasmic reticulum (Chanrion et al., 2007; Sucic et al., 2011), underscoring the power of proteomics approaches to identify novel SERT regulatory mechanisms.

Here, we have used a complementary strategy using the entire $\mathrm{C}$ terminus of SERT as bait to identify additional brain partners of SERT recruited by interaction motifs located upstream to its 15 C-terminal amino acids. We found that SERT interacts with both the catalytic and regulatory subunits of calcineurin $(\mathrm{CaN})$, a $\mathrm{Ca}^{2+}$-calmodulin-activated protein phosphatase enriched in brain, which has been involved in synaptic plasticity and in the mechanism of action of SSRI antidepressants (Mansuy, 2003; Crozatier et al., 2007; Baumgärtel and Mansuy, 2012). These experiments were complemented by a series of in vitro and in vivo studies to determine the impact of CaN activity and CaN/SERT interaction upon 5-HT transport via SERT. We also explored the effect of cerebral CaN activation in a behavioral paradigm relevant for antidepressant action.

\section{Materials and Methods}

Materials. $\left[{ }^{3} \mathrm{H}\right]-5-\mathrm{HT}$ creatine sulfate (95 Ci/mmol), $\left[{ }^{3} \mathrm{H}\right]$-citalopram (82 Ci/mmol), $\left[{ }^{3} \mathrm{H}\right]$-dihydroxyphenylethylamine dopamine $(38.7 \mathrm{Ci} /$ $\mathrm{mmol})$, and $\left[{ }^{3} \mathrm{H}\right]$-norepinephrine hydrochloride $(14.9 \mathrm{Ci} / \mathrm{mmol})$ were purchased from PerkinElmer. Oligonucleotides were from Eurogentec. The cell culture media and antibiotics were from Invitrogen. All chemicals were from Sigma-Aldrich.

Plasmids encoding CA-CaNA (pCMV-Flag/CA-CaNA) and PDCaNA (pCMV-Flag/PD-CaNA) were kindly provided by Dr. JeanAntoine Girault (Institut du Fer à Moulin, Paris). The CA-CaNA (constitutively active calcineurin A mutant) construct bears a deletion of the auto-inhibitory domain (398-521). The PD-CaNA (phosphatasedead calcineurin A mutant) construct bears the same deletion (398-521) and a mutation in the catalytic domain $\left(\mathrm{D}^{130} \mathrm{~N}\right)$. The plasmid encoding CaNB (pCMV-CaNB-Flag) was provided by Dr. Alain Lilienbaum (University Paris-Diderot). The plasmids encoding YFP-tagged human SERT (pEYFP/SERT), dopamine transporter (DAT, pEYFP/DAT), and norepinephrine transporter (NET, pEYFP/NET) were kindly provided by Dr. Michael Freissmuth (Medical University of Vienna). The pEYFP/ SERT $\triangle \mathrm{CaN}$ construct was obtained by mutating the CaN binding site in the human SERT sequence $\left({ }^{596}\right.$ RLIIT ${ }^{600}$ to ${ }^{596}$ ALAAA $\left.{ }^{600}\right)$.

The mouse monoclonal anti-GFP antibody (mixture of clones 7.1 and 13.1) was from Roche Diagnostics, the rabbit polyclonal anti-GFP antibody from Invitrogen, the rabbit polyclonal anti-SERT antibody from ImmunoStar, the rabbit polyclonal anti-CaNA and CaNB antibody from Millipore Bioscience Research Reagents, the rabbit polyclonal antiCaNA antibody from Millipore, the mouse monoclonal anti-CaNA antibody and the polyclonal anti-Flag antibody from Sigma-Aldrich, and the rabbit anti-GAPDH antibody from Santa Cruz Biotechnology.

Animals. CN279 (with inducible expression of a constitutively active $\mathrm{CaN}$ in forebrain neurons) and 211 (with inducible expression of $\mathrm{CaN}$ auto-inhibitory domain (211) in forebrain neurons) mice were described previously (Mansuy et al., 1998; Malleret et al., 2001). In both models, transgene expression was induced by doxycycline (dox) treatment $(6 \mathrm{mg}$ of dox for $100 \mathrm{~g}$ of wet food, administered daily for $12 \mathrm{~d}$ ). Control mice were littermates of double transgenic mice (CN279 or 211) that carried either no transgene or either one of each of the transgenes ( $r t T A 2$, tetO$\triangle C A M-A I$, or tetO-211 transgenes). They were similarly treated with dox, as previously described (Mansuy et al., 1998; Malleret et al., 2001). All mice have the same genetic background (C57BL/6J) and were backcrossed $>15$ times.

Mice were maintained in standard laboratory conditions (12 h light/ dark cycle with light on at 07:30 A.M.; room temperature $21^{\circ} \mathrm{C}$ ), with food and water ad libitum. Experiments conformed to European ethics standards (86/609-EEC), to decrees of the French National Ethics Com- mittee (87/848) and to guidelines and regulations of the Cantonal Veterinary Office, Zürich, for the care and use of laboratory animals.

Cell culture and transfection. HEK-293 cells were grown at $37^{\circ} \mathrm{C}$ in a $5 \%$ $\mathrm{CO}_{2}$ humidified atmosphere, in DMEM supplemented with $10 \%$ dialyzed FCS. Transfection was performed by electroporation using the BioRad Gene Pulser X cell. Immunocytofluorescence experiments indicated that $>50 \%$ of the cells were transfected with SERT, DAT, NET, and CaN constructs.

For experiments using siRNAs, cells were transfected in suspension with $200 \mathrm{~nm}$ of either CaNA Predesigned Mission siRNA (SigmaAldrich) or Universal Negative Control siRNA (Sigma-Aldrich) and $1 \mu \mathrm{g}$ YFP-SERT plasmid using Lipofectamine (Invitrogen). Cells were used $40 \mathrm{~h}$ after transfection. Downregulation of CaNA expression was analyzed by Western blotting using the polyclonal anti-CaNA antibody.

Primary cultures of mesencephalic neurons were prepared from 13-dold mouse embryos, as previously described (Chamak and Prochiantz, 1989). Briefly, cells were plated on polyornithine-coated 12-well culture dishes $\left(1 \times 10^{6}\right.$ cells/well $)$ in serum-free medium consisting of DMEM/ F12 (1:1), 33 mm D-glucose, $2 \mathrm{~mm}$ L-glutamine, $13 \mathrm{~mm} \mathrm{NaHCO}$, $5 \mathrm{~mm}$ HEPES, pH 7.4, and supplemented with $10 \%$ of hormone and salt mixture $(25 \mu \mathrm{g} / \mathrm{ml}$ insulin, $100 \mu \mathrm{g} / \mathrm{ml}$ transferrin, $60 \mu \mathrm{M}$ putrescine, $20 \mathrm{nM}$ progesterone, and $30 \mathrm{~nm}$ sodium selenite). Cultures were maintained at $37^{\circ} \mathrm{C}$ in a humidified atmosphere in $5 \% \mathrm{CO}_{2}$ and used $8 \mathrm{~d}$ after seeding.

GST pull-down assays. A PCR fragment corresponding to the entire SERT C-terminal domain (RLIITPGTFKERIIKSITPETPTEIPCGDIRLNAV, SERT-Ct) was subcloned into the pGEX-3X bacterial expression vector (GE Healthcare). A total of $50 \mu \mathrm{g}$ of GST or GST-SERT-Ct fusion proteins (produced in BL-21 cells) was immobilized onto glutathione Sepharose beads (GE Healthcare) and incubated overnight at $4^{\circ} \mathrm{C}$ with 1 $\mathrm{mg}$ (for Western blotting) or $10 \mathrm{mg}$ (for proteomics analysis) of mice brain proteins solubilized in $50 \mathrm{~mm}$ Tris- $\mathrm{HCl}, \mathrm{pH}$ 7.4, $0.5 \mathrm{~mm}$ EDTA, $1.3 \%$ CHAPS, and a protease inhibitor mixture (Roche). Samples were washed four times with $50 \mathrm{~mm}$ Tris- $\mathrm{HCl}, \mathrm{pH} 7.4,0.5 \mathrm{M} \mathrm{NaCl}$, and retained proteins were separated by SDS-PAGE or 2-D electrophoresis, as previously described (Chanrion et al., 2007).

Protein identification by mass spectrometry. Protein identification was performed by mass spectrometry using two different procedures. In the first one, protein spots detected on 2-D gels obtained from pull-downs with GST-SERT-Ct and absent in gels from control pull-downs were excised, digested in gel with trypsin (Gold; Promega), and peptides were analyzed using an Ultraflex MALDI-TOF mass spectrometer (Bruker Daltonik). Analyses were performed in reflectron mode with an accelerating voltage of $25 \mathrm{kV}$ and a delayed extraction of $50 \mathrm{~ns}$. The spectra were analyzed using the FlexAnalysis software (version 2.4, Bruker Daltonik), and autoproteolysis products of trypsin (molecular weights, 842.51, $1045.56,2211.10$, and 2383.90) were used as internal calibrates. Identification of proteins was performed using the Mascot software (version 2.0.04, Matrix Science; http://www.matrixscience.com/) against the mouse entries of Sprot or Trembl databases (downloaded on 2005-0515). The following parameters were used for database interrogation: mass tolerance of $50 \mathrm{ppm}$ (even if the mass accuracy of our analyses was usually better than $20 \mathrm{ppm}$ ); fixed chemical modification, carbamidomethylation of cysteines; variable chemical modification, oxidation of methionines; and one missed cleavage accepted and significance threshold $p<0.05$. In the second procedure, pulled-down proteins were separated by SDS-PAGE and systematically identified by nano-flow liquid chromatography coupled to Fourier transform tandem mass spectrometry (nano-LC-FT-MS/MS) using a LTQ-Orbitrap-XL (Thermo Fisher Scientific), as previously described (Meffre et al., 2012). MS/MS spectra were searched against the mouse Complete Proteome Set database (downloaded on 2012-07-15) by using Mascot (version 2.3) with trypsin enzyme specificity and up to two trypsin missed cleavages. Methionine oxidation was set as variable modification for searches. A peptide mass tolerance of $7 \mathrm{ppm}$ and a fragment mass tolerance of $0.5 \mathrm{Da}$ were allowed for identification. Peptide validation and peptide counting were performed using the MyProMS version 2.3 Web server (Poullet et al., 2007), to obtain a false discovery rate $<1 \%$. Only proteins identified with two or more peptides by MS/MS were considered as potential SERT partners. 
For each procedure, the experiments were repeated three times to assess reproducibility.

Analysis of SERT phosphorylation status by MS/MS. YFP-SERT expressed in HEK-293 cells was immunoprecipitated using the GFP-Trap kit (Chromotek). Immunoprecipitated proteins were separated by SDSPAGE, and the bands corresponding to SERT were digested with trypsin. Peptides were analyzed by nano-LC-FT-MS/MS and searched against the human Complete Proteome Set database (downloaded on 2012-02-22) as described above, with phosphorylation of Ser, Thr, and Tyr as variable modifications. Ion signals corresponding to phosphorylated peptides were quantified from their extracted ion chromatograms manually extracted using Qual browser version 12.1 (Thermo Fisher Scientific) with a tolerance of $5 \mathrm{ppm}$ for mass deviation and normalized to signals of their nonphosphorylated counterparts.

Coimmunoprecipitation. CHAPS-solubilized proteins from mice brain ( $1 \mathrm{mg}$ of protein per condition) were incubated overnight at $4^{\circ} \mathrm{C}$ with 10 $\mu \mathrm{l}$ of anti-SERT antiserum or $10 \mu \mathrm{l}$ of rabbit nonimmune serum. Solubilized proteins from transfected HEK-293 cells (1 mg) were incubated with $1 \mu \mathrm{g}$ of anti-Flag antibody or control goat IgG. Immunocomplexes were captured by incubation with protein A-Sepharose beads (GE Healthcare) for $1 \mathrm{~h}$ at $4^{\circ} \mathrm{C}$. Beads were washed three times with $50 \mathrm{~mm}$ Tris- $\mathrm{HCl}, \mathrm{pH} 7.4$, and immunoprecipitated proteins were analyzed by Western blotting.

Western blotting. Proteins resolved on $10 \%$ or $13.5 \%$ SDS-PAGE were transferred electrophoretically onto nitrocellulose membranes (Hybond-C; GE Healthcare). Membranes were incubated in blocking buffer (Tris- $\mathrm{HCl} 50 \mathrm{~mm}, \mathrm{pH} 7.5, \mathrm{NaCl} 200 \mathrm{~mm}$, Tween 20, 0.1\% and 5\% skimmed dried milk) for $1 \mathrm{~h}$ at room temperature, and overnight with primary antibodies (rabbit anti-GFP 1/1000; mouse anti-GFP 1/500; rabbit anti-Flag 1/1000; rabbit anti-CaN A and B 1/1000; rabbit anti-CaNA 1/1000; mouse anti-CaNA 1/2000; rabbit anti-GAPDH 1/1000) in blocking buffer at $4^{\circ} \mathrm{C}$. They were washed three times with blocking buffer and incubated with horseradish peroxidase-conjugated anti-rabbit or antimouse antibodies (1:5000, GE Healthcare) for $1 \mathrm{~h}$ at room temperature. Immunoreactivity was detected with an enhanced chemiluminescence method (ECL detection reagent, GE Healthcare).

Luciferase assay. HEK-293 cells electroporated with the NFAT-Luc plasmid in the presence or absence of CaN constructs were lysed with Glo Lysis Buffer (Promega), and luciferase activity in cell lysates was determined using the Bright-Glo Luciferase Assay (Promega), according to the manufacturer's instructions.

5-HT, dopamine, and norepinephrine uptake assays. HEK-293 cells grown in 96-well culture dishes were washed in HEPES buffer $(\mathrm{NaCl} 150 \mathrm{~mm}, \mathrm{KCl}$ $4.2 \mathrm{~mm}, \mathrm{CaCl}_{2} 0.9 \mathrm{~mm}, \mathrm{MgSO}_{4} 0.5 \mathrm{~mm}$, glucose $5 \mathrm{~mm}$, HEPES $10 \mathrm{~mm}, \mathrm{pH} 7.4$ ) and incubated for $10 \mathrm{~min}$ at $37^{\circ} \mathrm{C}$ in HEPES buffer containing $100 \mu \mathrm{M}$ pargyline and $100 \mu \mathrm{M}$ ascorbic acid. 5-HT uptake was initiated by the addition of $\left[{ }^{3} \mathrm{H}\right]-5$-HT (20 nM) and increasing concentrations of cold 5-HT ranging from 0.1 to $50 \mu \mathrm{M}$ (for $10 \mathrm{~min}$ at $37^{\circ} \mathrm{C}$ ) and terminated by three washes with ice-cold HEPES buffer containing $10 \mu \mathrm{m}$ of fluoxetine, followed by cell lysis in $1 \%$ SDS. Nonspecific 5-HT uptake was determined in the presence of 10 $\mu \mathrm{M}$ of fluoxetine. For 5-HT uptake into cultured mesencephalon neurons, cultures were plated in 12-well culture dishes, pretreated as indicated above, and uptake was initiated by the addition of $100 \mathrm{~nm}\left[{ }^{3} \mathrm{H}\right]-5-\mathrm{HT}$. Nonspecific 5-HT uptake was determined in the presence of $50 \mathrm{~nm}$ fluoxetine. The radioactivity incorporated into cells was determined by scintillation counting.

Dopamine and norepinephrine uptake was performed in HEK-293 cells using a procedure similar to that used for $\left[{ }^{3} \mathrm{H}\right]-5-\mathrm{HT}$ uptake. Uptake was initiated by the addition of $\left[{ }^{3} \mathrm{H}\right]$-dopamine $(20 \mathrm{~nm})$ or $\left[{ }^{3} \mathrm{H}\right]$ norepinephrine hydrochloride $(20 \mathrm{nM})$ and increasing concentrations of cold dopamine or norepinephrine ranging from 0.5 to $30 \mu \mathrm{M}$. Determination of nonspecific uptake was performed in the presence of $5 \mu \mathrm{M}$ of GBR12909 and $10 \mu \mathrm{M}$ of imipramine, respectively.

Biotinylation assay. Biotinylation was performed in transfected HEK293 cells using the Cell Surface Isolation kit (Pierce), according to the manufacturer's instructions. Briefly, $48 \mathrm{~h}$ after transfection, cells were washed in ice-cold PBS, pH 8.0, and incubated with $1 \mathrm{mg} / \mathrm{ml}$ of sulfoNHS-SS-biotin under gentle agitation for $30 \mathrm{~min}$ at $4^{\circ} \mathrm{C}$. After washing, cells were scraped off in $1 \mathrm{ml}$ of lysis buffer and lysates were spun at $8000 \times g$ for $10 \mathrm{~min}$. Clarified cell lysates were then incubated overnight
A
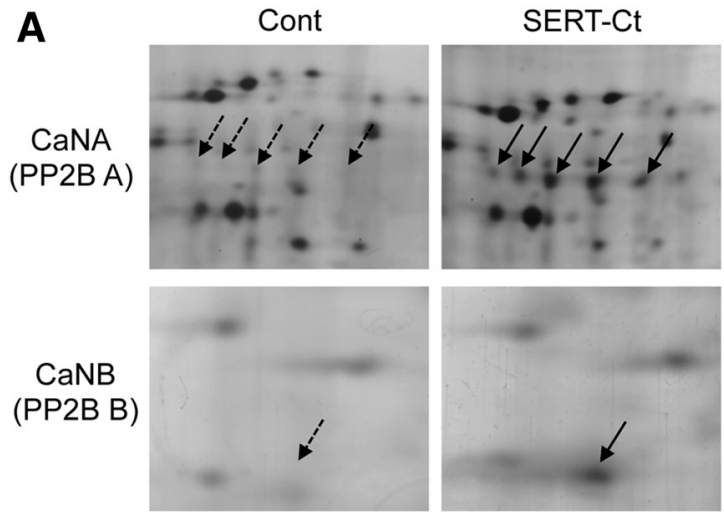

B

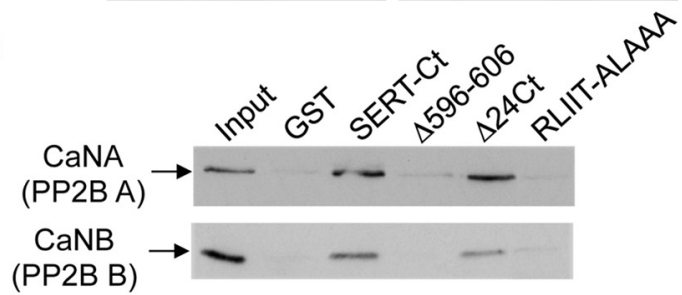

GST- RLIITPGTFKERIIKSITPETPTEIPCGDIRLNAV GST- -ERIIKSITPETPTEIPCGDIRLNAV

GST- RLIITPGTFK

GST-ALAAAPGTFKERIIKSITPETPTEIPCGDIRLNAV

SERT-Ct

$\triangle 596-606$

$\Delta 24 \mathrm{Ct}$

C

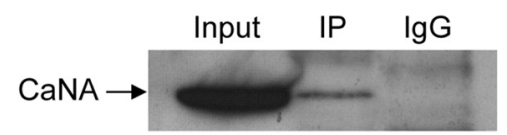

Figure 1. SERT C terminus interacts with the catalytic and regulatory subunits of calcineurin. $\boldsymbol{A}$, CHAPS-solubilized protein extracts from mice brain ( $10 \mathrm{mg}$ of protein) were incubated with $50 \mu \mathrm{g}$ of either GST fused to the SERT C-terminal domain (SERT-Ct) or GST alone (Control), immobilized on gluthatione-Sepharose beads. Proteins retained by affinity were resolved onto 2-D gels. Areas of silver-stained gels representative of three experiments performed independently and including spots corresponding to CaNA and CaNB (indicated by arrows) are represented. B, Protein extracts ( $1 \mathrm{mg}$ of protein) were pulled down with the indicated GST fusion proteins and analyzed by Western blotting with the polyclonal anti-CaN antibody, which recognizes both CaNA and CaNB. C, Protein extracts (1 $\mathrm{mg}$ of protein) were immunoprecipitated (IP) with the polyclonal anti-SERT antibody or with rabbit $\lg \mathrm{G}$, and immunoprecipitates were analyzed by Western blotting with the mouse anti-CaNA antibody. $B, C$, Data are representative of three independent experiments. Inputs represent $2 \%$ of the total protein amount used for pull-downs or immunoprecipitations.

at $4^{\circ} \mathrm{C}$ with $200 \mu \mathrm{l}$ of neutravidin-agarose beads. The beads were washed three times in lysis buffer and once in Tris- $\mathrm{HCl} 50 \mathrm{~mm}, \mathrm{pH}$ 7.4, and proteins retained on the beads were eluted with $100 \mu$ of SDS sampling buffer. The amount of SERT was analyzed in lysates and eluates (biotinylated fraction) by Western blotting, using the monoclonal anti-GFP antibody.

Preparation of synaptosomes and synaptosomal 5-HT uptake. Synaptosomes were prepared according to the method described by Kolomiytseva et al. (2008). Briefly, brains from CN279 or 211 mice and their corresponding controls were gently homogenized with a glass-Teflon homogenizer in 10 volumes of ice-cold buffer containing $50 \mathrm{~mm}$ Tris$\mathrm{HCl}, \mathrm{pH} 7.4,0.32 \mathrm{M}$ sucrose, and the protease inhibitor mixture (Roche). The homogenates were centrifuged at $1500 \times g$ for $10 \mathrm{~min}$ at $4^{\circ} \mathrm{C}$. Supernatants were then centrifuged at $9000 \times g$ for $20 \mathrm{~min}$. The pellets were resuspended in $0.32 \mathrm{~m}$ HEPES buffered, $\mathrm{pH} 7.4$, sucrose solution, and layered over $0.8 \mathrm{M}$ HEPES-buffered sucrose solution. After centrifugation at $9000 \times g$ for $25 \mathrm{~min}$, the synaptosomal fraction in the $0.8 \mathrm{M}$ sucrose layer was diluted to obtain a final $0.32 \mathrm{M}$ sucrose solution and centrifuged at $9500 \times g$ for $20 \mathrm{~min}$. The final pellet (purified synaptosomal fraction) was gently resuspended in Krebs-Ringer bicarbonate medium containing $150 \mathrm{~mm} \mathrm{NaCl}, 4.2 \mathrm{~mm} \mathrm{KCl}, 0.9 \mathrm{~mm} \mathrm{CaCl}_{2}, 0.5 \mathrm{~mm} \mathrm{MgSO}_{4}, 25 \mathrm{~mm}$ $\mathrm{NaHCO}_{3}, 10$ mм HEPES, pH 7.4, 5 mm glucose, and protease inhibitors, 
Table 1. Identification of Calcineurin subunits by MALDI-TOF mass spectrometry ${ }^{a}$

\begin{tabular}{|c|c|c|c|c|c|c|c|c|c|}
\hline Peptide & Start & End & $M / z$ (Obs) & $\operatorname{Mr}(\operatorname{Exp})$ & $\operatorname{Mr}$ (Calc) & $\delta$ & $\begin{array}{l}\text { Missed } \\
\text { cleavage }\end{array}$ & Sequence & Modification \\
\hline \multicolumn{10}{|c|}{$\begin{array}{l}\text { CaNA (isoform } \alpha \text { ): } 11 \text { peptides; protein score: 132; protein } \\
\text { mass: } 59,291 \text { Da; peptide coverage: } 25 \%\end{array}$} \\
\hline 1 & 143 & 148 & 762.49 & 761.4786 & 761.4799 & -0.001 & 0 & K.TLFLLR & \\
\hline 2 & 20 & 28 & 1007.55 & 1006.5437 & 1006.5348 & 0.009 & 0 & K.AVPFPPSHR & \\
\hline 3 & 64 & 73 & 1072.65 & 1071.6405 & 1071.6288 & 0.012 & 0 & R.IITEGASILR & \\
\hline 4 & 280 & 289 & 1117.55 & 1116.5398 & 1116.4948 & 0.045 & 0 & R.AHEAQDAGYR & \\
\hline 5 & 324 & 332 & 1152.55 & 1151.5477 & 1151.5393 & 0.008 & 0 & K.YENNVMNIR & \\
\hline 6 & 33 & 42 & 1176.58 & 1175.5759 & 1175.557 & 0.019 & 0 & K.EVFDNDGKPR & \\
\hline 7 & 101 & 112 & 1247.64 & 1246.6361 & 1246.6305 & 0.006 & 0 & K.LFEVGGSPANTR & \\
\hline 8 & 113 & 122 & 1260.64 & 1259.6346 & 1259.6186 & 0.016 & 0 & R.YLFLGDYVDR & \\
\hline 9 & 244 & 254 & 1369.66 & 1368.6549 & 1368.6534 & 0.002 & 0 & K.TQEHFTHNTVR & \\
\hline 10 & 488 & 501 & 1489.75 & 1488.7407 & 1488.6878 & 0.053 & 0 & R.DAMPSDANLNSINK & \\
\hline 11 & 425 & 441 & 1571.89 & 1570.8787 & 1570.8388 & 0.040 & 0 & K.GLTPTGMLPSGVLSGGK & 0xidation (M) \\
\hline \multicolumn{10}{|c|}{$\begin{array}{l}\text { CaNB (isoform 1): } 5 \text { peptides; protein score: } 56 \text {; protein } \\
\text { mass: 19,244 Da; peptide coverage: } 35 \%\end{array}$} \\
\hline 1 & 117 & 124 & 906.43 & 905.42 & 905.45 & -0.02 & 0 & K.MMVGNNLK & \\
\hline 2 & 125 & 134 & 1187.65 & 1186.65 & 1186.62 & 0.03 & 0 & K.DTQLQQIVDK & \\
\hline 3 & 135 & 146 & 1274.67 & 1273.66 & 1273.63 & 0.04 & 1 & K.TIINADKDGDGR & \\
\hline 4 & 73 & 84 & 1369.73 & 1368.72 & 1368.69 & 0.03 & 0 & K.EFIEGVSQFSVK & \\
\hline 5 & 57 & 72 & 1783.86 & 1782.85 & 1782.83 & 0.02 & 0 & R.VIDIFDTDGNGEVDFK & \\
\hline
\end{tabular}

${ }^{a}$ The lists of peptides matching with the CaNA (isoform $\alpha$ ) and CaNB (isoform 1) sequences are shown. For each peptide identified, the position in protein sequence, experimental and calculated masses, number of trypsin missed cleavage, and sequence are indicated.

Table 2. Protein identification by LC-MS/MS ${ }^{a}$

\begin{tabular}{|c|c|c|c|c|c|c|c|c|c|}
\hline Peptide & Start & End & Score & $\mathrm{M} / \mathrm{z}$ (Obs) & $\operatorname{Mr}($ Exp) & $\operatorname{Mr}$ (Calc) & Missed cleavage & Sequence & Modification \\
\hline \multicolumn{10}{|c|}{ CaNA (isoform $\alpha$ ): 5 peptides; protein score: } \\
\hline \multicolumn{10}{|c|}{$\begin{array}{l}\text { 98; protein mass: } 59,291 \text { Da; peptide } \\
\text { coverage: } 15 \%\end{array}$} \\
\hline 1 & 56 & 63 & 34.2 & 458.7583 & 915.5021 & 915.5025 & 0 & R.LEESVALR & \\
\hline 2 & 155 & 163 & 23.9 & 593.2999 & 1184.5853 & 1184.5866 & 0 & R.HLTEYFTFK & \\
\hline 3 & 101 & 112 & 56.0 & 624.3219 & 1246.6292 & 1246.6306 & 0 & K.LFEVGGSPANTR & \\
\hline 4 & 113 & 122 & 29.6 & 630.8168 & 1259.6191 & 1259.6186 & 0 & R.YLFLGDYVDR & \\
\hline 5 & 425 & 441 & 65.0 & 794.4231 & 1586.8317 & 1586.8338 & 0 & K.GLTPTGMLPSGVLSGGK & 0xidation (M) \\
\hline \multicolumn{10}{|c|}{$\begin{array}{l}\text { CaNA (isoform } \beta \text { ): } 4 \text { peptides; protein score: } \\
\text { 63; protein mass: } 59,721 \text { Da; peptide } \\
\text { coverage: } 11 \%\end{array}$} \\
\hline 1 & 164 & 172 & 23.9 & 593.2999 & 1184.5853 & 1184.5866 & 0 & R.HLTEYFTFK & \\
\hline 2 & 110 & 121 & 56.0 & 624.3219 & 1246.6292 & 1246.6306 & 0 & K.LFEVGGSPANTR & \\
\hline 3 & 122 & 131 & 29.6 & 630.8168 & 1259.6191 & 1259.6186 & 0 & R.YLFLGDYVDR & \\
\hline 4 & 147 & 157 & 29.7 & 668.4056 & 1334.7966 & 1334.7962 & 0 & K.ILYPSTLFLLR & \\
\hline \multicolumn{10}{|c|}{$\begin{array}{l}\text { CaNB (isoform 1): } 2 \text { peptides; protein score: } \\
\text { 24; protein mass: } 19,402 \text { Da; peptide } \\
\text { coverage: } 11 \%\end{array}$} \\
\hline 1 & 29 & 57 & 18.1 & 1101.5567 & 3301.6482 & 3301.65 & 1 & K.KLDLDNSGSLSVEEFMSLPELQQNPLVQR & 0xidation (M) \\
\hline $2^{b}$ & 148 & 165 & 24.2 & 513.0169 & 2048.0383 & 2048.0401 & 1 & R.ISFEEFCAVVGGLDIHKK & \\
\hline \multicolumn{10}{|c|}{$\begin{array}{l}\text { Calmodulin: } 2 \text { peptides; protein score: } \\
\text { 29; protein mass: } 16,827 \text { Da; peptide } \\
\text { coverage: } 22 \%\end{array}$} \\
\hline 1 & 92 & 107 & 28.7 & 585.6269 & 1753.859 & 1753.8635 & 1 & R.VFDKDGNGYISAAELR & \\
\hline 2 & 15 & 31 & 23.3 & 615.6347 & 1843.8824 & 1843.884 & 1 & K.EAFSLFDKDGDGTITTK & \\
\hline
\end{tabular}

${ }^{a}$ For each peptide identified, the position in protein sequence, Mascot score, experimental and calculated masses, number of trypsin missed cleavage and sequence are indicated.

${ }^{b}$ For CaNB (isoform 1), peptide 2 did not meet the score requirements set for our experiment but was considered as a genuine identification after manual validation.

and saturated with $95 \%$ air $/ 5 \% \mathrm{CO}_{2}$. Protein concentration was determined using the bicinchoninic acid method.

Synaptosomes $(0.5 \mathrm{mg}$ per assay) were preincubated with pargyline $(100 \mu \mathrm{M})$ and ascorbic acid $(100 \mu \mathrm{M})$ in $0.5 \mathrm{ml}$ of Krebs-Ringer bicarbonate buffer for $10 \mathrm{~min}$ at $37^{\circ} \mathrm{C}$. 5 - $\mathrm{HT}$ transport assays $\left(10 \mathrm{~min}\right.$ at $\left.37^{\circ} \mathrm{C}\right)$ were initiated by the addition of $\left[{ }^{3} \mathrm{H}\right]-5-\mathrm{HT}(20 \mathrm{~nm})$ and increasing concentrations of cold 5-HT ranging from 0.05 to $2 \mu \mathrm{M}$, and terminated by filtering the samples through $0.3 \%$ polyethylenimine-coated glass fiber filters (Whatman GF/C) by using a Brandel cell harvester. Nonspecific $\left[{ }^{3} \mathrm{H}\right]-5-\mathrm{HT}$ uptake was determined in the presence of $10 \mu \mathrm{M}$ of fluoxetine. $\left[{ }^{3} \mathrm{H}\right]$-Citalopram binding. Plasma membrane-enriched fractions (O'Malley et al., 2003) from brains of CN279 or 211 mice or corresponding control mice were incubated with increasing concentrations of $\left[{ }^{3} \mathrm{H}\right]$ citalopram ranging from 0.125 to $20 \mathrm{~nm}$ for $2 \mathrm{~h}$ at $25^{\circ} \mathrm{C}$ in $500 \mu$ lof binding buffer containing $50 \mathrm{~mm}$ Tris- $\mathrm{HCl}, \mathrm{pH} 7.4,120 \mathrm{~mm} \mathrm{NaCl}$, and $5 \mathrm{~mm} \mathrm{KCl}$. Assays were terminated by rapid filtration of the samples through $0.3 \%$ polyethylenimine-coated glass fiber filters (Whatman GF/C) using the Brandel cell harvester. Nonspecific binding was determined in the presence of 10 $\mu \mathrm{M}$ fluoxetine.

Behavioral tests. Behavioral tests were performed by an experimenter blinded to genotype and treatment. The Porsolt Forced Swim Test (FST) 
A

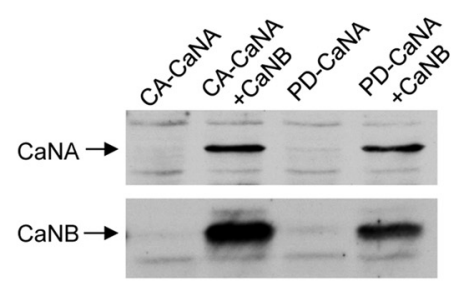

C
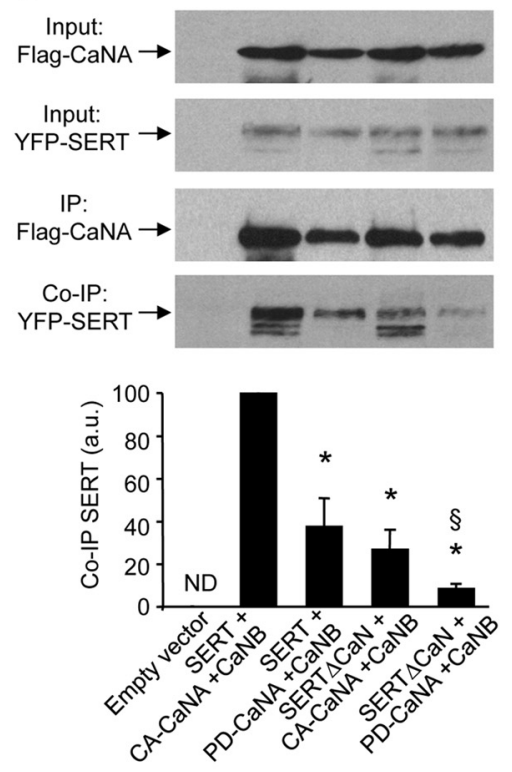

B

\section{D}
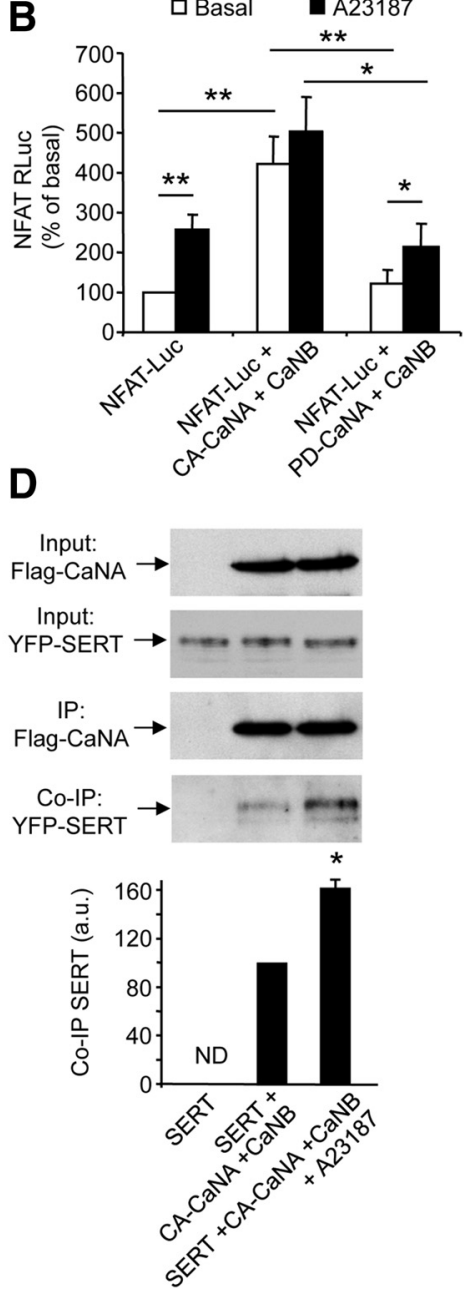

Figure 2. The interaction of SERT with calcineurin depends on calcineurin catalytic activity and $\mathrm{Ca}^{2+}$. $\boldsymbol{A}$, HEK-293 cells were transfected with either Flag-tagged CA-CaNA or Flag-tagged PD-CaNA vector, in the absence or presence of Flag-tagged CaNB vector. Total protein extracts were analyzed by Western blotting using a polyclonal anti-Flag antibody. B, HEK-293 cells were transfected with NFAT-Luc reporter plasmid in the absence or presence of CA-CaNA (+ CaNB) or PD-CaNA (+ CaNB) plasmids. Luciferase activity was measured in cells exposed or not to $10 \mu \mathrm{M}$ A23187 for $5 \mathrm{~min}$. Data are the mean \pm SEM of values obtained in three independent experiments performed in quadruplicate. ${ }^{*} p<0.05,{ }^{* *} p<0.01$. C, D, HEK-293 cells were cotransfected with plasmids encoding wild-type SERT or SERT mutated on the calcineurin interaction site (SERT $\triangle$ CaN) and either CA-CaNA (+ CaNB) or PD-CaNA ( + CaNB) plasmids (C) or cotransfected with plasmids encoding SERT and CA-CaNA (+ CaNB) and treated or not with $10 \mu \mathrm{m}$ A23187 for $5 \mathrm{~min}$ (D). Proteins were immunoprecipitated (IP) with a monoclonal anti-Flag antibody and analyzed by Western blotting using polyclonal anti-Flag (IP) and anti-GFP (Co-IP) antibodies. Representative blots are shown. Immunoreactive signals corresponding to SERT coimmunoprecipitated with CaNA were quantified and normalized to the corresponding CaNA signals in immunoprecipitates. Quantification data are the mean \pm SEM of values obtained in three independent experiments. ND, Not detected. ${ }^{*} p<0.05$ versus cells expressing SERT and CA-CaNA ( + CaNB). ${ }^{\circledR} p<0.05$ versus cells expressing SERT $\Delta$ CaN and CA-CaNA ( + CaNB).

was performed in a $5 \mathrm{~L}$ of plastic container $(20 \mathrm{~cm}$ diameter) filled $\left(\sim 80 \%\right.$ volume) with tap water at $18^{\circ} \mathrm{C}$ and an Ethovision system (Noldus) for automated video tracking. Recording time was 6 min at a sampling rate of 5 frames per seconds and threshold for immobility at default settings. Both males and females were used, and each mouse was tested only once. Groups consisted of $C N 279$ transgenic mice $(n=10)$ and their control littermates (mice carrying either no transgene or $r t T A 2$ or tetO$\triangle C A M-A I$ transgene, $n=8)$, of mixed age and gender: aged $(n=4)$ and young $(n=14)$, males $(n=14)$ and females $(n=4)$ mice. There was no statistical influence of age or gender.

Statistics. Data analysis and statistics were performed by using the GraphPad Prism 5 software. Data on Figures 2, 3, and 4 were analyzed by one-way ANOVA followed by Newman-Keuls or Dunnett's tests. The Mann-Whitney test was used to analyze the data on Figure 6A. Student's $t$ test was performed for statistical analysis of behavioral studies.

\section{Results}

The SERT C terminus interacts with the catalytic and regulatory subunits of calcineurin

The C-terminal domain of SERT fused to GST (GST-SERT-Ct) was conjugated to glutathione-Sepharose beads and incubated with detergent-solubilized protein extracts from mice brain. Control experiments were performed with beads conjugated to GST alone. Two-dimensional gel analysis of proteins retained by affinity revealed that two additional spots (or trains of spots) were specifically recruited by GST-SERT Ct (Fig. 1A), compared with our previous analyses using a peptide comprising only the $15 \mathrm{C}$-terminal amino acids of SERT as bait (Chanrion et al., 2007). These proteins were identified by MALDI-TOF mass spectrometry as CaNA (catalytic subunit, also designated as protein phosphatase 2B A) $\alpha$ isoform, and CaNB (regulatory subunit, also designated as protein phosphatase $2 \mathrm{~B} \mathrm{~B}$ ) isoform 1 (Table 1). Further supporting the association of CaN with SERT, shotgun analysis of proteins pulled-down with GST-SERT Ct by nano-LC-FT-MS/MS identified both $\alpha$ and $\beta$ isoforms of CaNA as well as CaNB isoform 1 (Table 2). Notably, calmodulin (CaM), which is known to tightly associate with $\mathrm{CaN}$ heterodimers (Liu, 2009), was also identified as a potential partner of SERT by this shotgun approach. Recruitment of CaN by SERT-Ct was further validated by Western blotting using a polyclonal antibody recognizing both $\mathrm{CaN}$ catalytic and regulatory subunits (Fig. 1B). Moreover, CaNA was specifically coimmunoprecipitated with native SERT expressed in mice brain (Fig. 1C), indicating that they form a complex in vivo.

We next generated truncation mutants of SERT-Ct and fused them to GST to characterize more precisely the CaN interaction domain within SERT C terminus. Deletion of the $10 \mathrm{~N}$-terminal amino acids of SERT C terminus almost completely prevented recruitment of CaNA and CaNB, whereas the deletion of the $24 \mathrm{C}$-terminal residues did not prevent association of CaN with SERT-Ct (Fig. 1B), indicating that the 10 $\mathrm{N}$-terminal amino acids of SERT-Ct were necessary and sufficient for its interaction with CaNA and CaNB. Based on existing similarities between the first five amino acids of this sequence (RLIIT) and CaNA binding motifs previously described in several proteins (Aramburu et al., 1998; Li et al., 2007; Takeuchi et al., 2007), we generated several constructs encoding SERT-Ct with one or several of these residues mutated into alanine. We found that replacement of the RLIIT sequence by ALAAA in SERT-Ct abrogated the interaction with CaNA and CanB (Fig. 1B), thus identifying the R-IIT sequence as a critical CaN binding motif in the SERT C terminus. We then introduced this modification into the entire SERT sequence 
(SERT $\Delta \mathrm{CaN}$ ) to analyze the role of SERT/ $\mathrm{CaN}$ physical interaction in living cells.

Interaction of calcineurin with SERT is a dynamic process regulated by calcineurin phosphatase activity and $\mathrm{Ca}^{2+}$

To further characterize SERT/CaN interaction, we transiently expressed in HEK-293 cells SERT in the absence or presence of a constitutively active CaNA (deleted of the CaM binding domain, CA-CaNA) or a phosphatase-dead, dominant-negative CaNA mutant (PD-CaNA) and of CaNB. As previously observed (Kahl and Means, 2004), coexpression of $\mathrm{CaNB}$ was required for expression of both CaNA mutants (Fig. 2A). Therefore, CaNB was systematically coexpressed with CA-CaNA or PD-CaNA in further experiments. We first performed luciferase assays using the NFAT-Rluc reporter gene, to assess $\mathrm{CaN}$ activity and to functionally validate the CaNA constructs. Exposure of cells to $10 \mu \mathrm{M}$ A23187, a Ca ${ }^{2+}$ ionophore, induced a twofold increase of basal activity in cells expressing NFAT-Rluc, which probably reflected activation of endogenous CaN (Fig. 2B). As expected, CACaNA expression elicited a strong luciferase response, which was not further enhanced by exposure of cells to A23187. In contrast, we did not detect any significant increase in luciferase activity in cells expressing PDCaNA (exposed or not to A23187), compared with cells expressing NFAT-Rluc alone.

We found that SERT was coimmunoprecipitated with both CA-CaNA and PDCaNA (Fig. 2C). However, the amount of SERT coimmunoprecipitated with PDCaNA was much lower than that found in CA-CaNA immunoprecipitates (Fig. 2C, lanes 2 and 3), suggesting that CaN activity promotes association of SERT with CaN. Consistent with this finding and further supporting a role of $\mathrm{Ca}^{2+}$ in SERT/CaN interaction, treating cells with A23187 $(10 \mu \mathrm{M}$, $5 \mathrm{~min}$ ) increased coimmunoprecipitation of SERT with CA-CaNA (Fig. 2D). As expected, the mutation of the ${ }^{596}$ RLIIT $^{600}$ sequence to ${ }^{596} \mathrm{ALAAA}^{600}$ in the CaN binding site of SERT (SERT $\Delta \mathrm{CaN}$ ) strongly reduced its ability to coimmunoprecipitate with CaN. Moreover, coimmunoprecipitation of SERT $\Delta \mathrm{CaN}$ with $\mathrm{CaN}$ was further decreased when this mutant SERT was coexpressed with PD-CaNA instead of CA-CaNA (Fig. 2C).

Calcineurin enhances 5-HT uptake and promotes SERT localization at the plasma membrane in HEK-293 cells Coexpression of CA-CaNA (and CaNB) with SERT in HEK-293 cells induced a marked increase in the velocity of 5-HT uptake, compared with cells expressing SERT alone $\left(\mathrm{V}_{\max }=6.68 \pm 1.18\right.$ vs $3.77 \pm 0.36 \mathrm{pmol} / \mathrm{min}, p<0.05$; Fig. $3 A, C)$. CA-CaNA expression did not significantly affect the apparent affinity of SERT
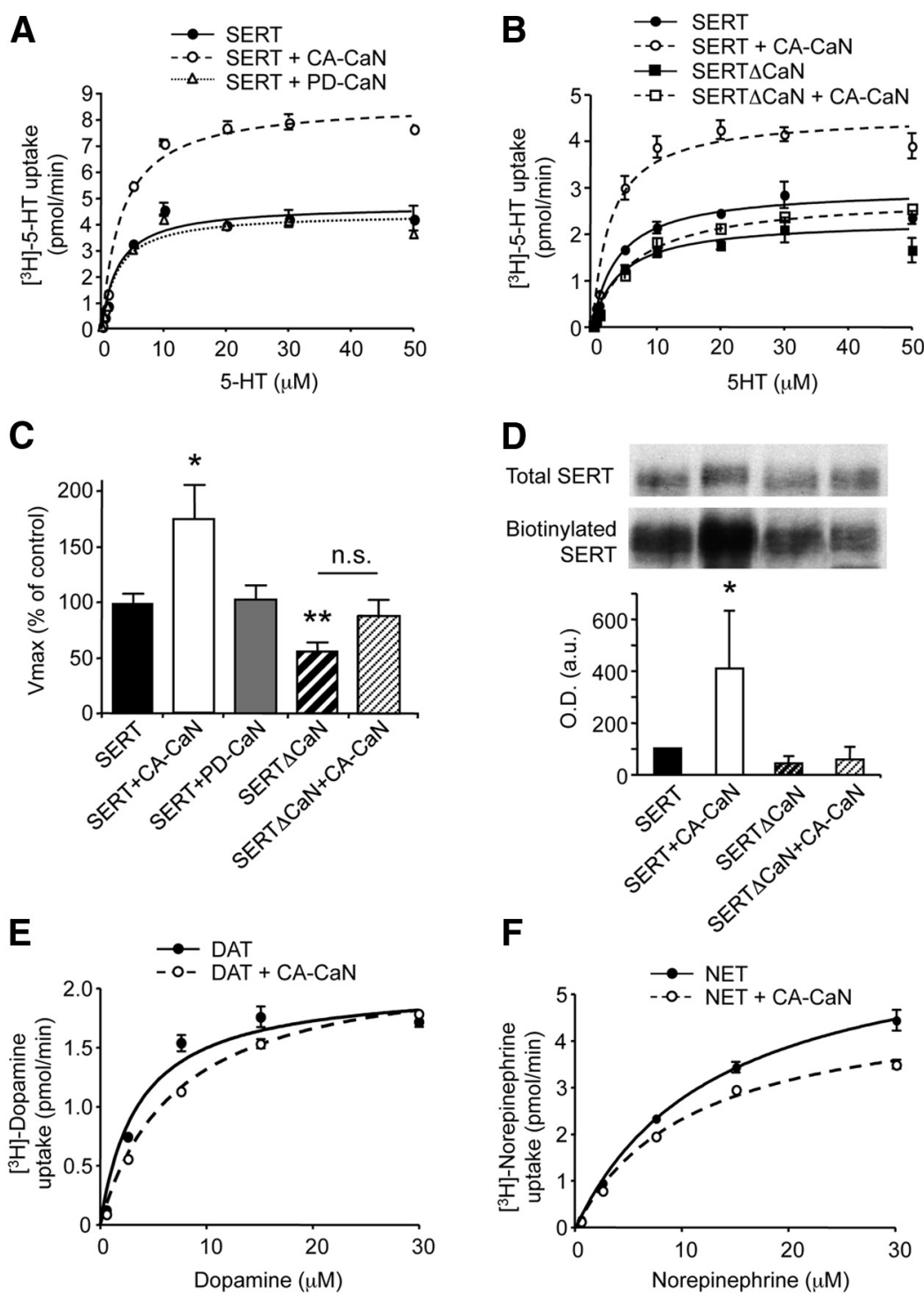

Figure 3. Calcineurin stimulates 5 -HT uptake and promotes SERT localization at the plasma membrane. $A,\left[{ }^{3} H\right]-5$-HT uptake in HEK-293 cells coexpressing SERT and CA-CaNA or PD-CaNA ( + CaNB). B, $\left[{ }^{3} \mathrm{H}\right]-5$-HT uptake in HEK-293 cells expressing SERT or SERT $\triangle$ CaN in the absence or presence of CA-CaNA ( + CaNB). Representative concentration-dependent curves are shown. C, Data represent the mean \pm SEM of $\mathrm{V}_{\max }$ of 5 -HT uptake (expressed in percentage of control value measured in cells expressing SERT alone, $3.77 \pm 0.36 \mathrm{pmol} / \mathrm{min}$ ) measured in three independent experiments performed on different sets of cultured cells. ${ }^{*} p<$ 0.05 versus cells expressing SERT alone. ${ }^{* *} p<0.01$ versus cells expressing SERT alone. n.s., Not significant. $\boldsymbol{D}$, Cell surface biotinylation assay performed on HEK-293 cells expressing SERT or SERT $\triangle$ CaN in the absence or presence of CA-CaNA ( + CaNB). Total and biotinylated SERT were detected by Western blotting using a monoclonal anti-GFP antibody. Representative blots are shown. Data, normalized to the amount of total SERT, are the mean \pm SEM of densitometric analyses of blots obtained in three independent experiments. ${ }^{*} p<0.05$ versus cells expressing SERT. $\boldsymbol{E},\left[{ }^{3} \mathrm{H}\right]$-Dopamine uptake in HEK-293 cells coexpressing DAT and CA-CaNA (+ CaNB). $\boldsymbol{F},\left[{ }^{3} \mathrm{H}\right]-$-Norepinephrine uptake in HEK-293 cells coexpressing NET and CA-CaNA ( + CaNB).

for $5-\mathrm{HT}\left(K_{\mathrm{m}}=2.93 \pm 0.47 \mu \mathrm{M}\right.$ in cells coexpressing SERT and CA-CaNA vs $2.72 \pm 0.19 \mu \mathrm{M}$ in cells expressing SERT alone). Coexpression of CA-CaNA (and CaNB) with DAT did not significantly modify the velocity of dopamine uptake in HEK-293 cells $\left(\mathrm{V}_{\max }=4.28 \pm 0.66 \mathrm{pmol} / \mathrm{min}\right.$ vs $3.35 \pm 0.61 \mathrm{pmol} / \mathrm{min}$ in cells expressing DAT alone, $p=0.73$; Fig. $3 E$ ), although it slightly but significantly decreased norepinephrine uptake in cells expressing NET $\left(\mathrm{V}_{\max }=4.66 \pm 0.15 \mathrm{pmol} / \mathrm{min}\right.$ vs $6.94 \pm 0.21$ $\mathrm{pmol} / \mathrm{min}$ in cells expressing NET alone, $p<0.05$; Fig. $3 F$ ).

In line with the increased 5-HT uptake in cells expressing CA-CaNA, biotinylation experiments indicated an increase in the proportion of SERT at the cell surface in cells coexpressing SERT 
A
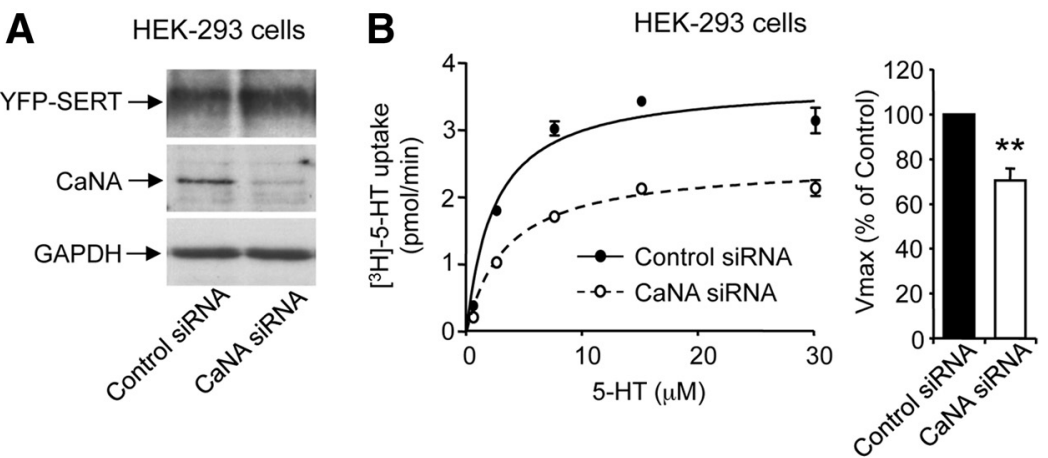

C

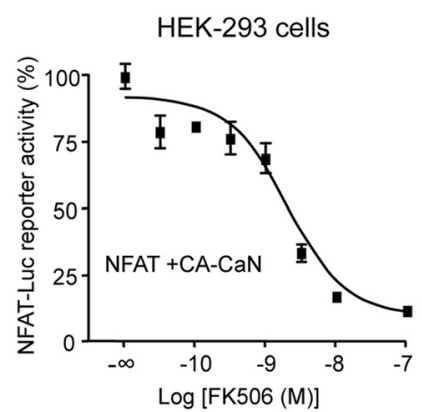

D

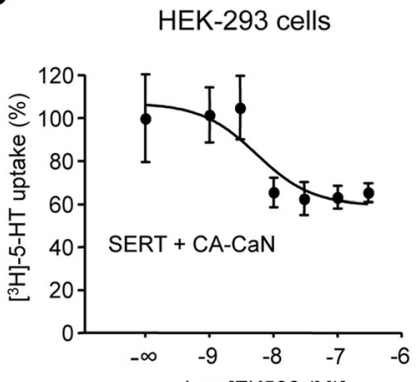

$\mathbf{E}$

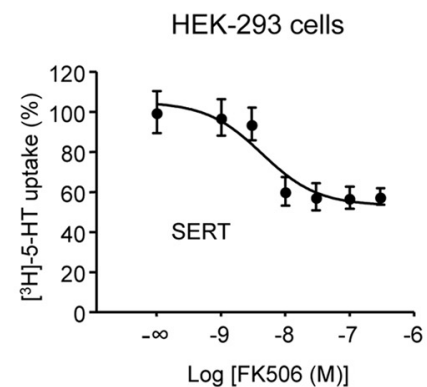

$\mathbf{F}$

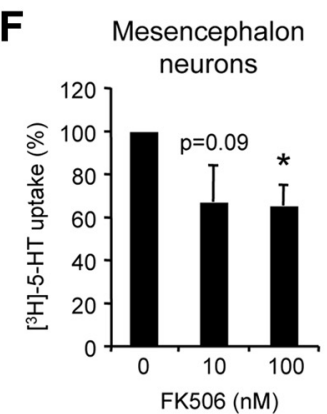

Figure 4. Silencing calcineurin expression and a pharmacological inhibitor of calcineurin decrease 5-HT uptake via SERT. A, HEK-293 cells were transfected with the plasmid encoding SERT and control or CaNA siRNA. Total protein extracts were analyzed by Western blotting using the monoclonal anti-GFP antibody, the polyclonal anti-CaNA antibody, and the anti-GAPDH antibody. $\boldsymbol{B},\left[{ }^{3} \mathrm{H}\right]-5$-HT uptake in HEK293 cells expressing SERT in the presence of control or CaNA siRNA. A representative experiment is shown. Data for $\mathrm{V}_{\max }$ of 5 -HT uptake, expressed in percentage of value in cells transfected with control siRNA $(3.78 \pm 0.49 \mathrm{pmol} / \mathrm{min})$, are the mean $\pm \mathrm{SEM}$ of values measured in three independent experiments. ${ }^{* *} p<0.01$ versus cells transfected with control siRNA.C, Effect of increasing concentrations of FK506 upon NFAT-Luc reporter activity in HEK-293 cells expressing CA-CaNA and CaNB. D, E, Effect of FK506 on [ $\left.{ }^{3} \mathrm{H}\right]-5$-HT uptake in HEK-293 cells transiently expressing SERT and CA-CaNA ( + CaNB) (D) or expressing SERT alone (E). Data, expressed in percentage of values measured in the absence of FK506, are the mean \pm SEM of triplicate determinations obtained in a representative experiment. Two other independent experiments performed on different sets of cultured cells yielded similar results. $F$, Effect of FK506 on [ $\left.{ }^{3} \mathrm{H}\right]-5-\mathrm{HT}$ uptake in mouse mesencephalon neurons in primary culture. Data, expressed in percentage of value measured in the absence of FK506 (15.8 $\pm 2.8 \mathrm{fmol} / \mathrm{min})$, are the mean \pm SEM of the results obtained in five independent experiments performed on different sets of cultured neurons. ${ }^{*} p<0.05$ versus 5 -HT uptake in the absence of FK506.

and CA-CaNA, compared with cells expressing SERT alone (Fig. $3 D$ ). Coexpression of PD-CaNA with SERT did not modify maximal 5-HT uptake $\left(\mathrm{V}_{\max }=3.89 \pm 0.52 \mathrm{pmol} / \mathrm{min}, K_{\mathrm{m}}=2.24 \pm\right.$ $0.16 \mu \mathrm{M}$ in cells coexpressing SERT and PD-CaNA; Fig. $3 A$ ), suggesting that $\mathrm{CaN}$-elicited increase of 5-HT uptake was dependent on its phosphatase activity. Moreover, coexpression of CACaNA with SERT $\Delta$ CaN did not significantly affect maximal 5 -HT uptake $\left(\mathrm{V}_{\max }=3.34 \pm 0.57 \mathrm{pmol} / \mathrm{min}, K_{\mathrm{m}}=2.16 \pm 0.36\right.$ $\mu \mathrm{M}$ ) or SERT $\Delta \mathrm{CaN}$ plasma membrane expression (Fig. $3 B-D$ ). Notably, maximal 5-HT uptake was significantly decreased in cells expressing SERT $\Delta \mathrm{CaN}$ mutant alone $\left(\mathrm{V}_{\max }=2.14 \pm 0.31 \mathrm{pmol} /\right.$ min, $\left.K_{\mathrm{m}}=2.32 \pm 0.63 \mu \mathrm{M}\right)$, compared with cells expressing SERT $(p<0.01$; Fig. $3 B, C)$. This reduced 5 -HT uptake via SERT $\Delta$ CaN probably reflects its low ability to interact with endogenously ex- pressed $\mathrm{CaN}$ and thus suggests that SERT activity can be regulated by endogenous CaN. Consistent with this hypothesis, silencing CaNA expression in HEK-293 cells using a small interfering RNA decreased by $32 \pm 6 \%$ the maximal velocity of 5-HT uptake via SERT $(p<0.01$; Fig. $4 A, B)$.

\section{The calcineurin inhibitor FK506 decreases 5-HT uptake into HEK-293 cells and mesencephalon neurons} Collectively, these results suggested that both CaN phosphatase activity and its physical interaction with SERT might contribute to CaN-elicited enhancement of SERT transport activity. To further confirm the role of CaN enzymatic activity in the regulation of SERT transport activity, we then investigated the effect of the CaN inhibitor FK506 in HEK-293 cells coexpressing CACaNA and SERT. Using the NFAT luciferase reporter system, we showed that FK506 inhibited CaN activity in a concentration-dependent manner $\left(\mathrm{pIC}_{50}=\right.$ $8.69 \pm 0.24$ nM; Fig. 4C) and 5-HT uptake with a similar apparent affinity $\left(\mathrm{pIC}_{50}=\right.$ $8.26 \pm 0.47$ nM; Fig. 4D). Further supporting a modulation of SERT transport activity by endogenous $\mathrm{CaN}$, the $\mathrm{CaN}$ inhibitor decreased 5-HT uptake in HEK-293 cells expressing SERT alone in the same concentration range $\left(\mathrm{pIC}_{50}=8.36 \pm 0.32 \mathrm{nM}\right.$, Fig. $4 E)$, as well as in mouse mesencephalon neurons in primary culture $(67.0 \pm 17.1$ and $65.3 \pm 9.9 \%$ basal uptake, measured in neurons treated with 10 and $100 \mathrm{nM}$ FK506, respectively, Fig. 4F).

\section{Calcineurin prevents SERT}

phosphorylation and inhibition of 5HT uptake induced by a protein kinase C activator

Several studies have demonstrated that protein kinase $\mathrm{C}(\mathrm{PKC})$ activation inhibits 5-HT transport activity of SERT in both recombinant (HEK-293 cells) and native (platelets, synaptosomes) systems and that this effect is paralleled by an increase in SERT phosphorylation (Qian et al., 1997; Ramamoorthy et al., 1998; Jayanthi et al., 2005; Samuvel et al., 2005). We thus wondered whether CaN phosphatase activity could affect PKC-mediated SERT regulation. Consistent with these previous findings, we found that a pretreatment of HEK293 cells expressing SERT alone with the PKC activator $\beta$-phorbol 12-myristate 13-acetate (PMA, $100 \mathrm{nM}$ ) caused an $\sim 50 \%$ reduction of 5 -HT uptake (Fig. $5 A$ ). In contrast, PMA did not significantly affect 5-HT uptake in cells coexpressing SERT and CA-CaNA (Fig. 5A), indicating that $\mathrm{CaN}$ activity prevents PKC-induced inhibition of SERT transport activity.

Analysis by nano-LC-FT-MS/MS of SERT phosphorylation status in HEK-293 cells coexpressing or not CA-CaNA showed a phosphorylation of SERT at $\mathrm{Thr}^{616}$ located in the SITPET sequence of the transporter $\mathrm{C}$ terminus (Fig. $5 B$ ) and impor- 
tant for SERT plasma membrane localization and its uptake function (Ahmed et al., 2009). However, the relative quantification of the corresponding ion signal by mass spectrometry did not reveal any dephosphorylation of this residue in cells expressing CA-CaNA. In PMA-treated cells, we identified an additional phosphorylated peptide in the N-terminal domain of SERT $\left({ }^{30}\right.$ VVPTPGDKVESGQISNGYSAVPSPGA GDDTR $^{60}$; Fig. $5 B$ ), and the corresponding ion signal was much higher in PMA-treated cells than in cells exposed to vehicle (Fig. 5C). Moreover, expression of CA-CaNA significantly reduced the phosphorylation of this peptide in cells treated with PMA, whereas it did not affect its basal phosphorylation level measured in vehicle-treated cells (Fig. 5C), indicating that CaN prevents PKC-elicited SERT phosphorylation. Unfortunately, we could not unambiguously identify by MS/MS the phosphorylated residue of this peptide, which contains several serines and threonines, as the generated peptide fragments did not allow us to discriminate between a phosphorylation at $\operatorname{Ser}^{48}$ or at $\operatorname{Ser}^{52}$ (Fig. 5B).

\section{Calcineurin enhances 5-HT uptake in mouse brain}

To determine whether cerebral 5-HT uptake via SERT is likewise modulated by $\mathrm{CaN}$ activity, we compared the velocity of 5-HT uptake in synaptosomes from mice expressing or not CA-CaNA (CN279 mice) or a CaNA auto-inhibitory domain (211 mice) in an inducible manner. Consistent with the data obtained in HEK-293 cells, induction of CA-CaNA expression by dox in CN279 mice significantly increased synaptosomal 5-HT uptake $\left(\mathrm{V}_{\max }=5.65 \pm 0.37\right.$ $\mathrm{pmol} / \mathrm{min}$ vs $3.95 \pm 0.11 \mathrm{pmol} / \mathrm{min}$ in the corresponding control mice treated with dox, $p<0.05 ; K_{\mathrm{m}}=0.19 \pm 0.05$ vs $0.13 \pm$ $0.04 \mu \mathrm{M}, p=0.210$ ) (Fig. $6 A$ ). In line with the increase in 5-HT transport in $C N 279$ mice, we found that $\left[{ }^{3} \mathrm{H}\right]$-citalopram binding was significantly increased in plasma membrane-enriched fraction from $C N 279$ mice treated with dox $\left(B_{\max }=784 \pm 58\right.$ vs $637 \pm 59$ $\mathrm{fmol} / \mathrm{mg}$ of protein in control mice, $p<0.05 ; K_{\mathrm{d}}=5.78 \pm 0.85 \mathrm{vs}$ $7.21 \pm 0.73 \mathrm{nM}, p=0.223$ ) (Fig. 6C). Conversely, both synaptosomal 5 -HT uptake and $\left[{ }^{3} \mathrm{H}\right]$-citalopram binding to plasma membraneenriched fraction were significantly reduced by induction of the CaNA auto-inhibitory domain, compared with the corresponding control mice treated with dox $\left(\mathrm{V}_{\max }\right.$ of 5-HT uptake $=3.58 \pm 0.17$ vs $5.09 \pm 0.39 \mathrm{pmol} / \mathrm{min}$ in control mice, $p<0.05 ; K_{\mathrm{m}}=0.10 \pm 0.02$ vs $0.12 \pm 0.03 \mu \mathrm{M}, p=0.313 ; \mathrm{B}_{\max }=564 \pm 44 \mathrm{vs} 712 \pm 21 \mathrm{fmol} / \mathrm{mg}$ of protein, $p<0.05 ; K_{\mathrm{d}}=3.68 \pm 0.69 \mathrm{vs} 3.35 \pm 0.64 \mathrm{nM}, p=0.578$ ) (Fig. 6B,D).

Brain calcineurin expression decreases immobility time in the forced swim test

Collectively, these results support a role for CaN enzymatic activity in the control of cerebral 5-HT uptake. These findings, together with previous observations indicating an important role for CaN phosphatase activity in the mechanisms of action of antidepressants (Crozatier et al., 2007), led us to examine whether expression of CA-CaNA modifies behavior in the FST, a task assessing behavioral despair and used to evaluate the activity of antidepressants in rodents. We found that dox-treated CN279 mice spent approximately twice less time immobile than littermate controls in the FST, specifically during min 3-5 after their initial attempt to escape (Fig. 7), indicating antidepressant-like activity of $\mathrm{CaN}$.

\section{Discussion}

The reuptake of 5-HT into presynaptic nerve terminals via SERT is a critical factor that determines the activity of the serotonergic system. Over the past years, an increasing number of studies have pointed the complexity of the cellular mechanisms controlling SERT expression, localization, and transport activity. These include several phosphorylation events driven by various protein kinases and phosphatases and association of SERT with a number of protein partners 
A
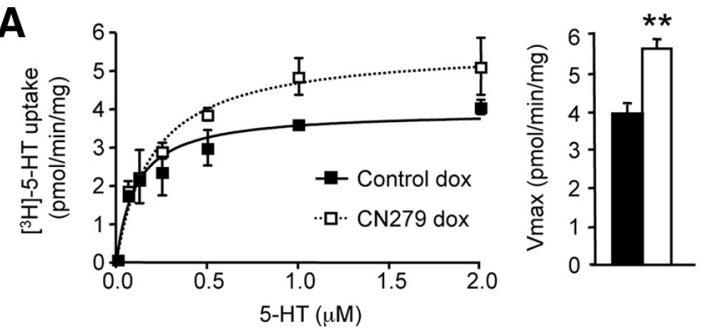

C
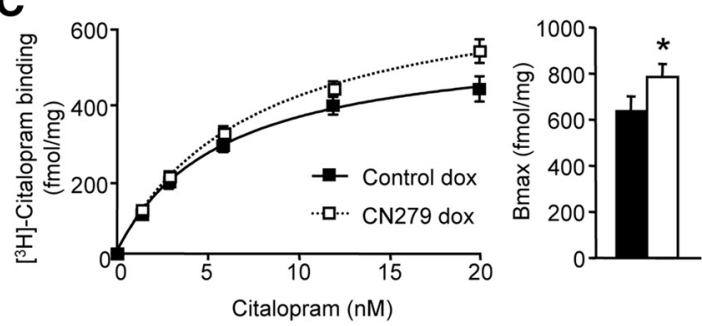
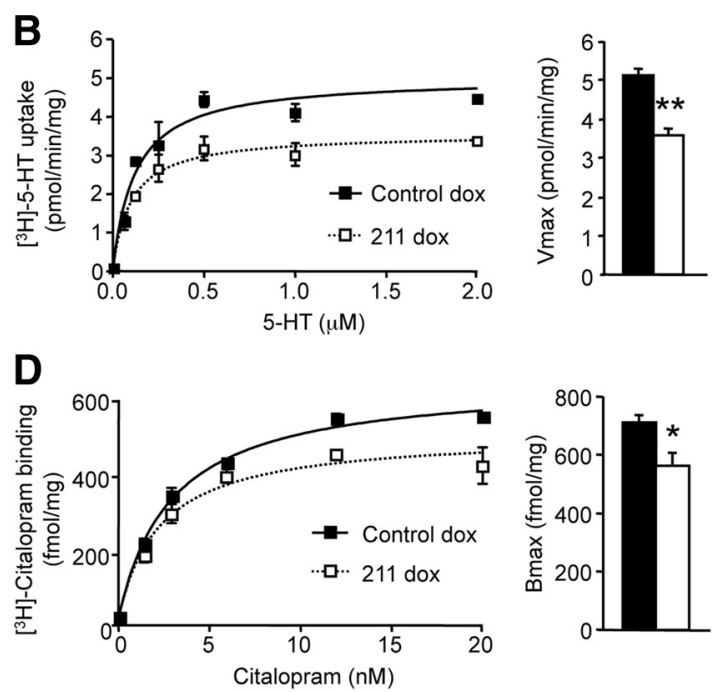

Figure 6. Calcineurin catalytic activity enhances cerebral 5-HT uptake. $A, B,\left[{ }^{3} \mathrm{H}\right]-5-\mathrm{HT}$ uptake in brain synaptosomes from CN279 or 211 mice and from their respective littermate control mice treated with dox for $12 \mathrm{~d}$. Representative dose-response curves obtained in synaptosomes purified from one mouse of each group are shown on the left. Means of $V_{\text {max }}$ values measured in the different groups ( $n=5-7$ mice per condition) are represented on the right. $C, D,\left[{ }^{3} \mathrm{H}\right]$-Citalopram binding measured on membrane preparations from brain of $C N 279$ or 211 mice and their respective controls treated with dox. Representative dose-response curves obtained in membrane-enriched fractions from one mouse of each group are shown on the left. Means of $B_{\max }$ values $(n=5-7$ mice per condition) are represented on the right. ${ }^{*} p<0.05$ vs corresponding control. ${ }^{* *} p<0.01$ vs corresponding control.

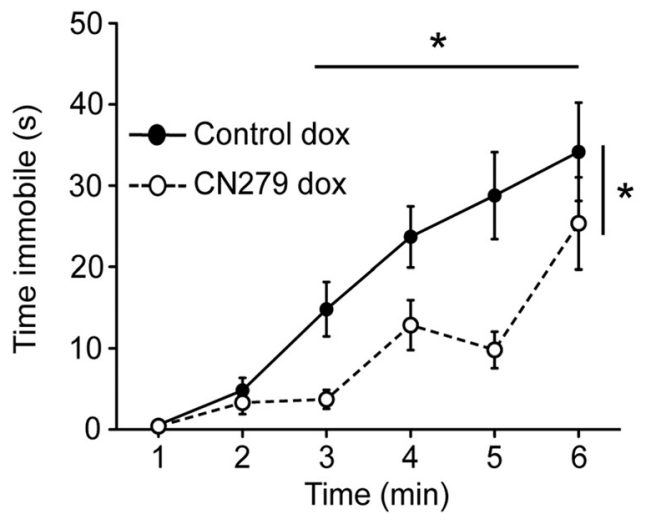

Figure 7. Calcineurin decreases immobility time in the forced swim test. Cumulative time spent immobile in CN279 and littermate control mice treated with dox for $12 \mathrm{~d}$ before the FST. CN279 mice spent less time immobile overall than controls $(n=10$ and 8 , respectively, $p<0.05)$, specifically during $\min 3-5$ after initial attempt to escape. Data are mean \pm SEM. ${ }^{*} p<0.05$.

(Zhong et al., 2012). Of these, protein phosphatase 2A (catalytic subunit) was shown to form a complex with SERT, which is dynamically regulated by 5-HT and PKC-dependent SERT phosphorylation and governs transporter phosphorylation and trafficking (Ramamoorthy et al., 1998; Bauman et al., 2000).

Here, we show a physical association of SERT with CaN, a brain-enriched, $\mathrm{Ca}^{2+} / \mathrm{CaM}$-activated phosphatase known to modulate key proteins essential for synaptic transmission and neuronal excitability (Baumgärtel and Mansuy, 2012). Consistent with the heterodimeric nature of $\mathrm{CaN}$, which consists of a catalytic CaNA subunit tightly associated with a myristoylated, $\mathrm{Ca}^{2+}$-binding regulatory CaNB subunit, we found that SERT C terminus associates with both CaNA and CaNB. Three isoforms of CaNA, CaNA $\alpha, \beta$, and $\gamma$ and two isoforms of CaNB, CaNB1, and CaNB2, have previously been described, whereas CaNA $\gamma$ and CaNB2 are found almost exclusively in the testis (Liu, 2009). Thus, only $\mathrm{CaNA} \alpha, \beta$, and $\mathrm{CaNB} 1$ are relevant in the brain. Our MS/MS analyses clearly identified these three isoforms, suggesting that both $\mathrm{CaNA} \alpha / \mathrm{CaNB} 1$ and $\mathrm{CaNA} \beta / \mathrm{CaNB} 1$ het- erodimers can associate with SERT C terminus. In contrast, our proteomic screen did not identify any catalytic subunit of protein phosphatase $2 \mathrm{~A}$, suggesting that other domains of SERT are involved in the recruitment of this phosphatase. Further validating the assembly of SERT/CaN complexes in vivo, CaNA was specifically coimmunoprecipitated with native SERT expressed in the adult brain in mice.

Consistent with a tight association of $\mathrm{CaN}$ heterodimers with $\mathrm{CaM}$, this protein was also identified in our shotgun analyses of SERT-associated complex, although it was not detected by 2-D gel analysis of proteins pulled down with SERT C terminus. This might be the result of the acidic nature of this protein, which makes its resolution and detection in 2-D gels difficult. The precise architecture of the complex formed by SERT, CaN heterodimer, and CaM also remains to be better defined. However, it is likely that SERT directly interacts with the CaNA subunit, as we identified in the proximal region of SERT C terminus a sequence sharing some similarities with previously identified CaNA binding motifs in various CaN partners (Aramburu et al., 1998), and the mutation of this motif almost completely abolished association of CaN with SERT.

The $\mathrm{Ca}^{2+} / \mathrm{CaM}$ complex has long been known to modulate 5-HT uptake via SERT (Jayanthi et al., 1994; Yura et al., 1996; Turetta et al., 2004). More recently, Ciccone et al. (2008) have shown that $\mathrm{Ca}^{2+} / \mathrm{CaM}$-dependent kinase II controls the transport stoichiometry of SERT by promoting SERT interaction with Syntaxin 1A. Here, we identified another mechanism whereby $\mathrm{Ca}^{2+} / \mathrm{CaM}$ can affect SERT functional status and which relies on $\mathrm{CaN}$ and its physical association with SERT. Interestingly, this interaction was itself dependent on both CaN phosphatase activity and cytosolic $\mathrm{Ca}^{2+}$. Indeed, coimmunoprecipitation experiments in transfected HEK-293 cells showed that CA-CaNA bound more efficiently to SERT than a phosphatase-dead CaNA mutant, and increasing cytosolic $\mathrm{Ca}^{2+}$ concentration further increased association of CA-CaNA to SERT. However, treating cells expressing CA-CaNA with a $\mathrm{Ca}^{2+}$ ionophore did not further enhance its constitutive phosphatase activity. This suggests that $\mathrm{Ca}^{2+}$ can promote and/or stabilize SERT/CaN interaction by ac- 
tivating $\mathrm{CaN}$ and by a $\mathrm{CaN}$-independent mechanism that remains to be elucidated.

Our results, based on a combination of genetic and pharmacological approaches, show that $\mathrm{CaN}$ catalytic activity enhances 5-HT transport via SERT and prevents the inhibitory action of PKC upon SERT functional activity. Indeed, the expression of CA-CaNA increased 5-HT uptake in HEK-293 cells, which was of comparable level in cells treated or not with a PKC activator, whereas expression of a phosphatase-dead mutant did not significantly affect the velocity of 5-HT transport.

Induction of expression of CA-CaNA in mice brain likewise increased the velocity of cerebral 5-HT uptake. Corroborating these findings and indicating a role of endogenous $\mathrm{CaN}$ in the regulation of SERT activity, both silencing CaNA expression and pharmacological inhibition of CaN by FK506 decreased 5-HT transport activity of SERT in vitro, and brain expression of the CaNA auto-inhibitory domain reduced cerebral 5-HT uptake. Notably, regulation of 5-HT uptake by $\mathrm{CaN}$ phosphatase activity correlated with its impact on SERT/CaN interaction. Further supporting a role of SERT/CaN interaction in CaN-elicited SERT functional activity, we found that mutating the CaN binding site in the SERT sequence reduced 5-HT transport. However, we cannot rule out that this mutation also affected SERT functionality via a mechanism independent of CaN binding. Finally, in contrast to the observed enhancement of SERT transport activity by $\mathrm{CaN}$ phosphatase activity, we found that coexpression of CACaNA with DAT did not affect the velocity of dopamine uptake in HEK-293 cells whereas it reduced the uptake of norepinephrine via NET, indicating that $\mathrm{CaN}$ differentially modulates the activity of monoamine transporters.

The molecular events underlying regulation of SERT transport function by $\mathrm{CaN}$ remain incompletely elucidated. Our data suggest that it might result, at least in part, from the ability of CaN phosphatase activity to modulate SERT plasma membrane expression. Indeed, expression of CA-CaN produced a concomitant increase in SERT cell surface expression and 5-HT transport, whereas expression of the CaN auto-inhibitory domain decreased both its plasma membrane expression and 5-HT uptake. In an effort to demonstrate whether SERT itself is a substrate of $\mathrm{CaN}$, we found that one Ser residue located in SERT N-terminal domain was phosphorylated upon exposure of cells to PMA and that expression of CA-CaNA reduced the phosphorylation of this Ser elicited by this treatment. This suggests that the ability of $\mathrm{CaN}$ to prevent the downregulation of SERT function caused by PKC activation might result from its capacity to directly dephosphorylate SERT. However, it is unlikely that this phosphorylation event underlies upregulation of SERT activity induced by $\mathrm{CaN}$ in the absence of PKC activator, as relative quantification of the corresponding ion signal by mass spectrometry did not reveal further dephosphorylation of this residue in cells expressing CACaNA and not treated with PMA. Likewise, CaN did not decrease the phosphorylation level of $\mathrm{Thr}^{616}$ located in the SITPET sequence of the transporter $\mathrm{C}$ terminus and important for SERT uptake function (Ahmed et al., 2009), indicating that CaNelicited upregulation of SERT activity does not result from $\mathrm{Thr}^{616}$ dephosphorylation. One cannot rule out that MS/MS analysis did not identify all phosphorylated residues in the transporter sequence, including other sites potentially dephosphorylated by $\mathrm{CaN}$, or that $\mathrm{CaN}$ dephosphorylates other proteins important for SERT trafficking in and out of the plasma membrane.

Increasing evidence suggests that $\mathrm{CaN}$ plays a pivotal role in the control of mood. Treatment of patients after heart transplantation with CaN inhibitors to prevent graft rejection is often accompanied by neuropsychiatric complications, such as depression and anxiety, which can be alleviated by switching the treatment to an mTOR inhibitor (Lang et al., 2009). Systemic administration of CaN inhibitors likewise induces depressionand anxiety-like behaviors in mice, an effect reproduced by local downregulation of $\mathrm{CaN}$ in amygdala using short hairpin RNAs targeting CaNA (Bahi et al., 2009). Corroborating these observations and indicating antidepressant-like activity of $\mathrm{CaN}$, induction of CaNA expression in the adult mouse brain (CN279 mice) decreased immobility time in the FST. In contrast, mice constitutively expressing CA-CaNA (CN98 mice) show no variation in immobility time and only increased sensitivity to antidepressant effects (Crozatier et al., 2007). This difference in depression-like behavior might reflect adaptive processes in CN98 mice. Conversely, decreased $\mathrm{CaN}$ activity was observed in rats exposed to chronic mild test and inhibition of hippocampal CA3 CaN exacerbated depressive-like behavior in these rats (Zhu et al., 2011). Finally, chronic treatment with an SSRI upregulated CaN protein expression in the hippocampus and mice that overexpress $\mathrm{CaN}$ in the hippocampus are more sensitive to the behavioral effects of antidepressants (Crozatier et al., 2007), suggesting that CaN would be an indirect target of antidepressants contributing to their effect upon mood.

Little is known about the cellular mechanisms that underlie the antidepressant-like effects of CaN. Although not expected given the opposite action of $\mathrm{CaN}$ and antidepressants upon 5-HT uptake, our results suggest that the behavioral effects of CaN might result from a modulation of SERT plasma membrane density and 5-HT transport activity. This hypothesis is consistent with previous findings indicating a decrease in SERT function in some depressed patients (Parsey et al., 2006a) and a greater risk for depression (associated to a decreased SERT expression) in individuals with the short serotonin transporter allele (Parsey et al., 2006b). They support the notion that a depressive state can be associated with decreased SERT density and/or 5-HT transport and underscore the importance of identifying the concomitant molecular, cellular, and neurochemical changes for a better understanding of the mechanisms leading to an increased risk for depression.

\section{References}

Ahmed BA, Jeffus BC, Bukhari SI, Harney JT, Unal R, Lupashin VV, van der Sluijs P, Kilic F (2008) Serotonin transamidates Rab4 and facilitates its binding to the $\mathrm{C}$ terminus of serotonin transporter. J Biol Chem 283: 9388-9398. CrossRef Medline

Ahmed BA, Bukhari IA, Jeffus BC, Harney JT, Thyparambil S, Ziu E, Fraer M, Rusch NJ, Zimniak P, Lupashin V, Tang D, Kilic F (2009) The cellular distribution of serotonin transporter is impeded on serotonin-altered vimentin network. PLoS One 4:e4730. CrossRef Medline

Aramburu J, Garcia-Cózar F, Raghavan A, Okamura H, Rao A, Hogan PG (1998) Selective inhibition of NFAT activation by a peptide spanning the calcineurin targeting site of NFAT. Mol Cell 1:627-637. CrossRef Medline

Bahi A, Mineur YS, Picciotto MR (2009) Blockade of protein phosphatase $2 \mathrm{~B}$ activity in the amygdala increases anxiety- and depression-like behaviors in mice. Biol Psychiatry 66:1139-1146. CrossRef Medline

Bauman AL, Apparsundaram S, Ramamoorthy S, Wadzinski BE, Vaughan RA, Blakely RD (2000) Cocaine and antidepressant-sensitive biogenic amine transporters exist in regulated complexes with protein phosphatase 2A. J Neurosci 20:7571-7578. Medline

Baumgärtel K, Mansuy IM (2012) Neural functions of calcineurin in synaptic plasticity and memory. Learn Mem 19:375-384. CrossRef Medline

Carneiro AM, Blakely RD (2006) Serotonin-, protein kinase C-, and Hic-5associated redistribution of the platelet serotonin transporter. J Biol Chem 281:24769-24780. CrossRef Medline

Carneiro AM, Cook EH, Murphy DL, Blakely RD (2008) Interactions between integrin alphaIIbbeta 3 and the serotonin transporter regulate serotonin transport and platelet aggregation in mice and humans. J Clin Invest 118:1544-1552. CrossRef Medline 
Chamak B, Prochiantz A (1989) Influence of extracellular matrix proteins on the expression of neuronal polarity. Development 106:483-491. Medline

Chanrion B, Mannoury la Cour C, Bertaso F, Lerner-Natoli M, Freissmuth M, Millan MJ, Bockaert J, Marin P (2007) Physical interaction between the serotonin transporter and neuronal nitric oxide synthase underlies reciprocal modulation of their activity. Proc Natl Acad Sci U S A 104:81198124. CrossRef Medline

Ciccone MA, Timmons M, Phillips A, Quick MW (2008) Calcium/ calmodulin-dependent kinase II regulates the interaction between the serotonin transporter and syntaxin 1A. Neuropharmacology 55:763-770. CrossRef Medline

Crozatier C, Farley S, Mansuy IM, Dumas S, Giros B, Tzavara ET (2007) Calcineurin (protein phosphatase 2B) is involved in the mechanisms of action of antidepressants. Neuroscience 144:1470-1476. CrossRef Medline

Haase J, Killian AM, Magnani F, Williams C (2001) Regulation of the serotonin transporter by interacting proteins. Biochem Soc Trans 29:722-728. CrossRef Medline

Jayanthi LD, Ramamoorthy S (2005) Regulation of monoamine transporters: influence of psychostimulants and therapeutic antidepressants. AAPS J 7:E728-E738. CrossRef Medline

Jayanthi LD, Ramamoorthy S, Mahesh VB, Leibach FH, Ganapathy V (1994) Calmodulin-dependent regulation of the catalytic function of the human serotonin transporter in placental choriocarcinoma cells. J Biol Chem 269:14424-14429. Medline

Jayanthi LD, Samuvel DJ, Blakely RD, Ramamoorthy S (2005) Evidence for biphasic effects of protein kinase $\mathrm{C}$ on serotonin transporter function, endocytosis, and phosphorylation. Mol Pharmacol 67:2077-2087. CrossRef Medline

Jess U, El Far O, Kirsch J, Betz H (2002) Interaction of the C-terminal region of the rat serotonin transporter with MacMARCKS modulates 5-HT uptake regulation by protein kinase C. Biochem Biophys Res Commun 294: 272-279. CrossRef Medline

Kahl CR, Means AR (2004) Calcineurin regulates cyclin D1 accumulation in growth-stimulated fibroblasts. Mol Biol Cell 15:1833-1842. CrossRef Medline

Kolomiytseva IK, Perepelkina NI, Zharikova AD, Popov VI (2008) Membrane lipids and morphology of brain cortex synaptosomes isolated from hibernating Yakutian ground squirrel. Comp Biochem Physiol B Biochem Mol Biol 151:386-391. CrossRef Medline

Lang UE, Heger J, Willbring M, Domula M, Matschke K, Tugtekin SM (2009) Immunosuppression using the mammalian target of rapamycin (mTOR) inhibitor everolimus: pilot study shows significant cognitive and affective improvement. Transplant Proc 41:4285-4288. CrossRef Medline

Larsen MB, Fjorback AW, Wiborg O (2006) The C-terminus is critical for the functional expression of the human serotonin transporter. Biochemistry 45:1331-1337. CrossRef Medline

Li H, Zhang L, Rao A, Harrison SC, Hogan PG (2007) Structure of calcineurin in complex with PVIVIT peptide: portrait of a low-affinity signalling interaction. J Mol Biol 369:1296-1306. CrossRef Medline

Liu JO (2009) Calmodulin-dependent phosphatase, kinases, and transcriptional corepressors involved in T-cell activation. Immunol Rev 228:184198. CrossRef Medline

Malleret G, Haditsch U, Genoux D, Jones MW, Bliss TV, Vanhoose AM, Weitlauf C, Kandel ER, Winder DG, Mansuy IM (2001) Inducible and reversible enhancement of learning, memory, and long-term potentiation by genetic inhibition of calcineurin. Cell 104:675-686. CrossRef Medline

Mansuy IM (2003) Calcineurin in memory and bidirectional plasticity. Biochem Biophys Res Commun 311:1195-1208. CrossRef Medline

Mansuy IM, Winder DG, Moallem TM, Osman M, Mayford M, Hawkins RD, Kandel ER (1998) Inducible and reversible gene expression with the rtTA system for the study of memory. Neuron 21:257-265. CrossRef Medline

Meffre J, Chaumont-Dubel S, Mannoury la Cour C, Loiseau F, Watson DJ, Dekeyne A, Séveno M, Rivet JM, Gaven F, Déléris P, Hervé D, Fone KC, Bockaert J, Millan MJ, Marin P (2012) 5-HT(6) receptor recruitment of mTOR as a mechanism for perturbed cognition in schizophrenia. EMBO Mol Med 4:1043-1056. CrossRef Medline

Millan MJ (2006) Multi-target strategies for the improved treatment of depressive states: conceptual foundations and neuronal substrates, drug discovery and therapeutic application. Pharmacol Ther 110:135-370. CrossRef Medline
Müller HK, Wiborg O, Haase J (2006) Subcellular redistribution of the serotonin transporter by secretory carrier membrane protein 2. J Biol Chem 281:28901-28909. CrossRef Medline

Murphy DL, Lesch KP (2008) Targeting the murine serotonin transporter: insights into human neurobiology. Nat Rev Neurosci 9:85-96. CrossRef Medline

O’Malley KL, Jong YJ, Gonchar Y, Burkhalter A, Romano C (2003) Activation of metabotropic glutamate receptor mGlu5 on nuclear membranes mediates intranuclear $\mathrm{Ca}^{2+}$ changes in heterologous cell types and neurons. J Biol Chem 278:28210-28219. CrossRef Medline

Parsey RV, Hastings RS, Oquendo MA, Huang YY, Simpson N, Arcement J, Huang Y, Ogden RT, Van Heertum RL, Arango V, Mann JJ (2006a) Lower serotonin transporter binding potential in the human brain during major depressive episodes. Am J Psychiatry 163:52-58. CrossRef Medline

Parsey RV, Hastings RS, Oquendo MA, Hu X, Goldman D, Huang YY, Simpson N, Arcement J, Huang Y, Ogden RT, Van Heertum RL, Arango V, Mann JJ (2006b) Effect of a triallelic functional polymorphism of the serotonin-transporter-linked promoter region on expression of serotonin transporter in the human brain. Am J Psychiatry 163:48-51. CrossRef Medline

Poullet P, Carpentier S, Barillot E (2007) myProMS, a web server for management and validation of mass spectrometry-based proteomic data. Proteomics 7:2553-2556. CrossRef Medline

Qian Y, Galli A, Ramamoorthy S, Risso S, DeFelice LJ, Blakely RD (1997) Protein kinase $\mathrm{C}$ activation regulates human serotonin transporters in HEK-293 cells via altered cell surface expression. J Neurosci 17:45-57. Medline

Ramamoorthy S, Giovanetti E, Qian Y, Blakely RD (1998) Phosphorylation and regulation of antidepressant-sensitive serotonin transporters. J Biol Chem 273:2458-2466. CrossRef Medline

Samuvel DJ, Jayanthi LD, Bhat NR, Ramamoorthy S (2005) A role for p38 mitogen-activated protein kinase in the regulation of the serotonin transporter: evidence for distinct cellular mechanisms involved in transporter surface expression. J Neurosci 25:29-41. CrossRef Medline

Steiner JA, Carneiro AM, Blakely RD (2008) Going with the flow: trafficking-dependent and -independent regulation of serotonin transport. Traffic 9:1393-1402. CrossRef Medline

Steiner JA, Carneiro AM, Wright J, Matthies HJ, Prasad HC, Nicki CK, Dostmann WR, Buchanan CC, Corbin JD, Francis SH, Blakely RD (2009) cGMP-dependent protein kinase Ialpha associates with the antidepressantsensitive serotonin transporter and dictates rapid modulation of serotonin uptake. Mol Brain 2:26. CrossRef Medline

Sucic S, El-Kasaby A, Kudlacek O, Sarker S, Sitte HH, Marin P, Freissmuth M (2011) The serotonin transporter is an exclusive client of the coat protein complex II (COPII) component SEC24C. J Biol Chem 286:16482-16490. CrossRef Medline

Takeuchi K, Roehrl MH, Sun ZY, Wagner G (2007) Structure of the calcineurin-NFAT complex: defining a T cell activation switch using solution NMR and crystal coordinates. Structure 15:587-597. CrossRef Medline

Torres GE, Gainetdinov RR, Caron MG (2003) Plasma membrane monoamine transporters: structure, regulation and function. Nat Rev Neurosci 4:13-25. CrossRef Medline

Turetta L, Donella-Deana A, Folda A, Bulato C, Deana R (2004) Characterisation of the serotonin efflux induced by cytosolic $\mathrm{Ca}^{2+}$ and $\mathrm{Na}+$ concentration increase in human platelets. Cell Physiol Biochem 14:377-386. Medline

White KJ, Walline CC, Barker EL (2005) Serotonin transporters: implications for antidepressant drug development. AAPS J 7:E421-E433. CrossRef Medline

Yura A, Kiuchi Y, Uchikawa T, Uchida J, Yamazaki K, Oguchi K (1996) Possible involvement of calmodulin-dependent kinases in $\mathrm{Ca}\left({ }^{2+}\right)$ dependent enhancement of $\left[{ }^{3} \mathrm{H}\right] 5$-hydroxytryptamine uptake in rat cortex. Brain Res 738:96-102. CrossRef Medline

Zhong H, Sánchez C, Caron MG (2012) Consideration of allosterism and interacting proteins in the physiological functions of the serotonin transporter. Biochem Pharmacol 83:435-442. CrossRef Medline

Zhu WL, Shi HS, Wang SJ, Wu P, Ding ZB, Lu L (2011) Hippocampal CA3 calcineurin activity participates in depressive-like behavior in rats. J Neurochem 117:1075-1086. CrossRef Medline 